\title{
Fat embolism in sickle cell disease
}

\author{
R. M. HUTCHINSON, M. V. MERRICK, AND J. M. WHITE \\ From the Departments of Haematology and Radiology, Hammersmith Hospital, London
}

SYNOPSIS Fat embolism is a known complication of marrow infarction in patients with sickle cell $\frac{\Omega}{\circ}$ disease $(\mathrm{Hb} \mathrm{S} / \mathrm{S}$ and $\mathrm{Hb} \mathrm{S} / \mathrm{C})$ disease. It should be considered in sickle cell crisis when there is deterioration in respiratory function, a fall in arterial $\mathrm{PO}_{2}$, a normoblastaemia, and a thrombocyto- $\infty$ penia in the peripheral blood. We now report a patient in whom the diagnosis was confirmed in life by identifying fat in the sputum, demonstrating disseminated intravascular coagulation, and using a $\mathcal{O}^{\circ}$ double isotope technique to distinguish recent from old marrow infarction. Use of these features 을 enabled an early diagnosis to be made which led to a successful outcome in a potentially fatal $\rightarrow$ condition.

Fat embolism is a well known complication of bone marrow infarction in patients with $\mathrm{Hb} \mathrm{S} / \mathrm{S}$ and $\mathrm{Hb}$ S/C disease (Charache and Page, 1967; Brown, 1972). This condition can progress rapidly to a fatal conclusion unless early diagnosis and treatment is initiated (Rywlin, Black, and Werner, 1963; Hendrickse and Watson Williams, 1966). In the case reported the diagnosis of pulmonary fat embolism was suspected on clinical and haematological grounds. Early confirmation was made by finding fat globules in the sputum, a low $\mathrm{P}_{\mathrm{art}} \mathrm{O}_{2}$ and the presence of disseminated intravascular coagulation.

A whole body scan following the intravenous injection of ${ }^{99} \mathrm{~T} \mathrm{c}^{\mathrm{m}}$-sulphur colloid confirmed that there was extensive bone marrow infarction, demonstrated the extent of the infarction, and indicated the most promising sites for biopsy.

\section{Case Summary}

The patient was a 19-year-old West Indian female known to suffer from sickle cell anaemia (Hb S $88 \%, \mathrm{Hb} \mathrm{F} 10 \%, \mathrm{Hb} \mathrm{\textrm {A } _ { 2 }} 2 \%$ ). She was admitted to hospital after a 12-day history of an influenzal-like illness associated with bronchitis, increasing lethargy, deepening jaundice, and dyspnoea. On examination she was febrile (temperature $99.5^{\circ} \mathrm{F}$ ) but no abnormal chest signs were noted. The spleen was not palpable. The investigations showed $\mathbf{H b} 7 \cdot 2 \mathrm{~g} / 100 \mathrm{ml}$ (it had previously been $10.0 \mathrm{~g} / 100 \mathrm{ml}$ ); WBC $14000 / \mu \mathrm{l}$, with $70 \%$ neutrophils; platelets $340000 / \mu 1$. A chest radiograph was normal. Before admission she had received ampicillin $250 \mathrm{mg}$ qds for five days. She

Received for publication 12 June 1973. was treated with Septrin 2 tablets bd and given fluids $\omega$ orally, 3-4 1 daily.

Over the next $48 \mathrm{hr}$ her condition deteriorated, with increasing pyrexia (temperature $100-104^{\circ} \mathrm{F}$ ) and increasing tachypnoea. Generalized crepitations appeared over the lung fields as well as signs of $\frac{\circ}{\circ}$ consolidation of the right lower lobe. She became restless, irritable, and developed pain in the mandible $\frac{0}{3}$ and right femur and anaesthesia over the area supplied by the mental branches of the inferior dental nerve. Her $\mathrm{Hb}$ had fallen to $5.2 \mathrm{~g} / 100 \mathrm{ml}$, platelets to $100000 / \mu \mathrm{l}$, and the WBC had risen to? $45000 / \mu \mathrm{l}$ (fig 1). Most of the nucleated cells in the blood were normoblasts, none having been seen in 3 . previous films. Myelocytes and megakaryocytes $\delta$ were also present. Her arterial $\mathrm{PO}_{2}$ was $62 \mathrm{~mm} \mathrm{Hg}$. At this time a diagnosis of marrow infarction, fat $\mathrm{O}$ embolism, and disseminated intravascular coagula- $\rightarrow$ tion was considered because of the association of the pulmonary findings, thrombocytopenia, and normo- $N$ blastaemia. The diagnosis was confirmed $24 \mathrm{hr}$ laterwhen fat both as free globules and inside histiocytes 0 was found in the sputum. Evidence suggestive of $\mathrm{e}_{\mathrm{J}}$ intravascular coagulation was the finding that theo fibrin degradation products were elevated to $16_{0}$ $\mu \mathrm{g} / \mathrm{ml}$. During this period she was treated with ${ }_{\varnothing}^{-}$ continuous oxygen $(60 \%)$, on which her arterial $\stackrel{\infty}{+}$ $\mathrm{PO}_{2}$ rose to $120 \mathrm{~mm} \mathrm{Hg}$, and she was transfused with 3 units of blood. Her clinical status improved rapidlyọ् although the chest signs responded slowly.

A whole body scan of the bone marrow was performed, starting 10 minutes after the iv injection of $6 \mathrm{mCi}$ of ${ }^{99} \mathrm{Tc}^{\mathrm{m}}$-sulphur colloid (Stern, McAfee, 
E.T.

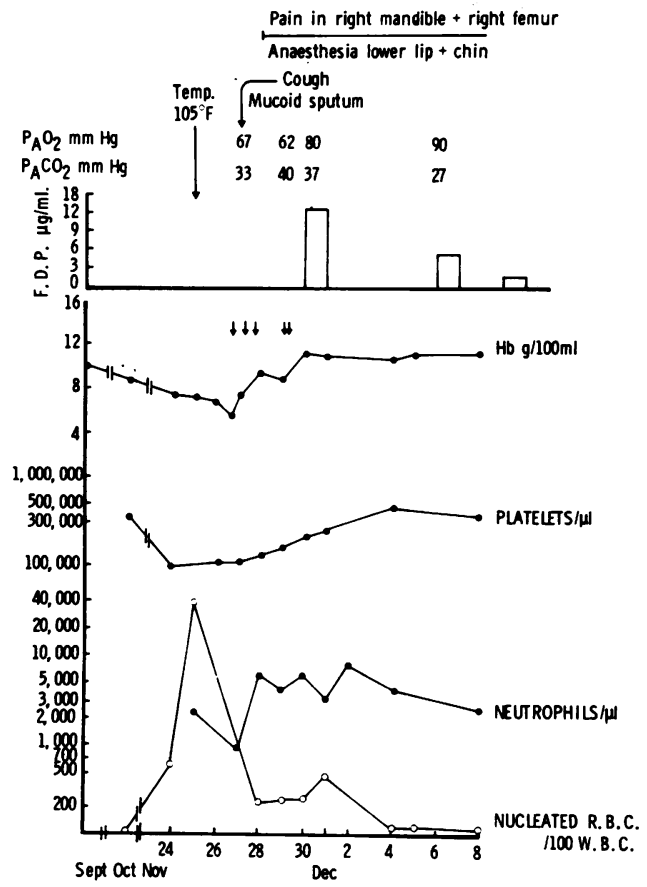

Fig 1 The haematological indices of the patient during her illness. Attention is drawn to the decrease in $\mathrm{Hb}$ level and platelet count associated with a marked increase in circulating normoblasts in the peripheral blood.

and Subramanian, 1966), using an Ohio nuclear model 84 whole body scanner fitted with twin 5 in. diameter $\times 2$ in. thick thallium-activated sodium iodide detectors, arranged to make simultaneous anterior and posterior scans. The findings were a generalized extension of marrow, but with the normal symmetry disturbed by multiple defects in the skull, left humerus, lumbar spine, pelvis, both femora, and both tibia (fig 2). Biopsy from the right ilium (arrowed) revealed only necrotic, pyknotic cells with no normal marrow. These findings confirmed that the infarction was recent. A further whole body scan two weeks later carried out one hour after the iv administration of $2 \mathrm{mCi}$ of ${ }^{18} \mathrm{~F}$ revealed increased activity in the areas in which recent infarction was suspected. This was evidence of increased bone turnover associated with replacement of infarcted tissue, and thus distinguished filling defects in the marrow due to recent infarction from those of longer duration (Merrick, 1973).

She was transfused with 3 more units of blood until her $\mathrm{Hb}$ had risen to $12 \mathrm{~g} / 100 \mathrm{ml}$ (the concentration of $\mathrm{Hb} \mathrm{S}$ was $15 \%$ at this time). The signs in the chest gradually disappeared and the platelet count rose

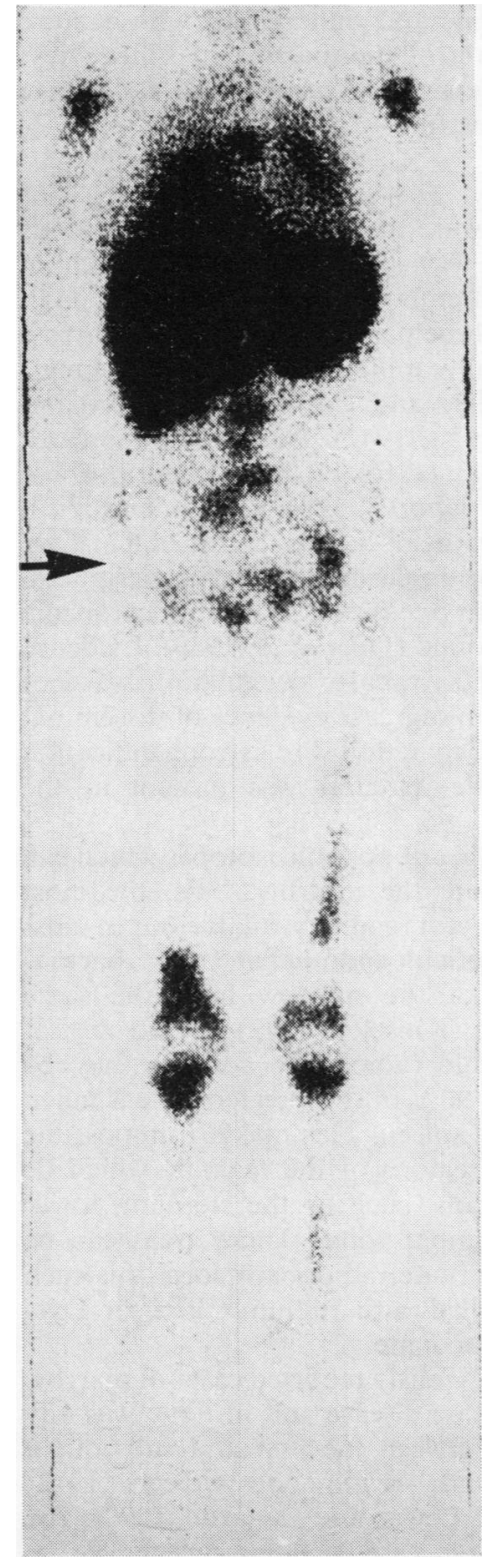

Fig 2 Bone marrow scan using technetium sulphur colloid. Note the absence of radioactivity over the right pelvis and femur. The arrow indicates the approximate site of the marrow biopsy.

with the disappearance of normoblasts and a decrease in the fibrin degradation products from the blood. She was discharged two weeks after admission.

Four weeks later she was well and the pain in the right femur had disappeared, though the anaesthesia over the jaw was still present. The haemoglobin was $10 \cdot 2 \mathrm{~g} / 100 \mathrm{ml}$, WBC $5000 / \mu \mathrm{l}$, and platelet count $370000 / \mu \mathrm{l}$. A repeat bone marrow scan showed active 
marrow in the pelvis and right femur with a more uniform distribution of the marrow in other sites; however, a bone marrow biopsy of the right iliac crest was not successful.

\section{Discussion}

As far as we are aware there have been no previous reports of patients with sickle cell anaemia in whom the diagnosis of fat embolism has been confirmed in life. At necropsy these patients had fat and marrow emboli in the small capillaries of the brain, lungs, and kidneys (Shelley and Curtis, 1958; Wertham, Mitchell, and Angrist, 1942). In none of the cases was the sputum stained for fat before death. There are no detailed reports of the haematological findings of these patients before death but in four of the cases a normoblastaemia in the peripheral blood was noted. In one report a thrombocytopenia of $82000 / \mu \mathrm{l}$ was found (Ober et al, 1959). Evidence of disseminated intravascular coagulation was not sought. However, in our case evidence of disseminated intravascular coagulation was a strong indication that thromboplastic material was present in the circulation.

There are a number of possible isotopes which can be used to delineate the marrow. ${ }^{52} \mathrm{Fe}$, the most logical, is however, not readily available but in most conditions the reticuloendothelial and haemopoietic functions of the marrow have the same spatial distribution (Kniseley, 1972) so that any of the readily available radioactive colloids may be used. However, $80-90 \%$ of the injected dose is taken up by the liver and spleen. This makes it impossible to examine those regions of the marrow which lie close to these organs, such as the sternum, lower ribs, and upper lumbar spine. These areas can be visualized with alternate radiopharmaceuticals such as transferrin labelled with Indium (111In) or Dysprosium $\left({ }^{157} \mathrm{Dy}\right)$ gluconate.

There are few previously reported cases of marrow scanning in sickle cell disease and in none was any change observed between the first and subsequent scans (Alavi, Bond, Kuhl, and Creech, 1972; Denardo, Hammel, Lewis, and Denardo, 1972). The finding in the present case of filling defects on the first scan, some of which were not present two months later, is confirmation that infarcted marrow may regenerate. Bone scans performed with ${ }^{18} \mathrm{~F}$ indicate regions of new bone formation associated with the removal of infarcted trabecular bone along with its infarcted marrow. These changes will not be detectable radiologically. It is anticipated that ${ }^{85} \mathrm{Sr}$ should be as effective as ${ }^{18} \mathrm{~F}$.

Double scanning, with colloid and ${ }^{18} \mathrm{~F}$, is thus more specific than the colloid scan alone, but there is no direct evidence how long it takes for the ${ }^{18} \mathrm{~F}$ scan to become abnormal in this condition. Extrapolating from the observations made following trauma, the likely period is one to two weeks.

The apparent high mortality associated with fat embolism in patients with $\mathrm{Hb} \mathrm{S} / \mathrm{S}$ and $\mathrm{Hb} \mathrm{S} / \mathrm{C}$ disease contrasts with the low mortality when fat embolism occurs from bone trauma in patients with $\mathrm{Hb}$ A. It is likely that the two most serious factors in fat embolism in both groups are hypoxia and intravascular coagulation (Bradford, Foster, and Nossel, 1970) and both would initiate a vicious circle of further sickling and infarction in patients with sickle cell syndromes. The degree of hypoxia is ? particularly important, since in vivo all erythrocytes containing only $\mathrm{Hb} \mathrm{S}$ will probably sickle if the arterial $\mathrm{PO}_{2}$ falls below $50 \mathrm{~mm} \mathrm{Hg}$.

We suggest that fat embolism should always be considered in patients with a sickle cell crisis, $\frac{\text { ? }}{3}$ especially when it is accompanied by rapidly $\overrightarrow{ }$ deteriorating respiratory signs, a fall in arterial $\mathrm{PO}_{2}$, the presence of numerous circulating normoblasts in the peripheral blood, and thrombocyto- $\stackrel{\rho}{+}$ penia. Evidence of disseminated intravascular $\vec{\varphi}$ coagulation should be looked for. We believe that $\omega$ heparin therapy (as suggested by Hendrikse and Watson-Williams, 1966) in addition to continuous oxygen and rapid transfusion will reverse this potentially fatal condition.

One of us (M.V.M.) is in receipt of an MRC grant (number G. 689).

\section{References}

Alavi, A., Bond, J. P., Kuhl, D. E., and Creech, R. H. (1972). Scan detection of bone marrow infarcts in sickle cell anemia. $J$. nucl. Med., 13, 408.

Bradford, D. S., Foster, R. R, and Nossel, H. L. (1970). Coagulation $\frac{\Omega}{O}$ alterations, hypoxemia and fat embolism in fracture patients. J. Trauma, 10, 307-321.

Brown, C. H. (1972). Bone marrow necrosis: a study of seventy cases. Johns Hopk. med. J., 131, 189-203.

Charache, S., and Page, D. L. (1967). Infarction of bone marrow in the sickle cell disorders. Ann intern. Med., 67, 1195-1200.

Denardo, S. J., Hammel, C. F., Lewis, J. P., and Denardo, G. L. 음 (1972). Assessment of bone and marrow in sickle cell disease. J. nucl. Med., 13, 425-426.

Hendrickse, J. P. D., and Watson-Williams, E. J. (1966). The influence of hemoglobinopathies on reproduction. Amer. J. Obstet. $\frac{\mathrm{N}}{\mathrm{N}}$ Gynec., 94, 739-748.

Kniseley, R. M. (1972). Marrow studies with radiocolloids. Sem. nucl. Med., 2, 71-85.

Merrick, M. V. (1973). The current status of bone scanning. La Ricerca in Clinice e Laboratoria, 2 , in press.

Ober, W. B., Brunc, M. S., Simon, R. M., and Weiner, L. (1959). $\sigma$ Hemoglobin S.C. Disease with fat embolism. Amer. J. Med., 27, 658-674.

Rywlin, A. M., Block, A. L., and Werner, C. S. (1963). Hemoglobin C $\frac{C}{D}$ and $S$ disease in pregnancy. Amer. J. Obstet. Gynec., 86, 10551059.

Shelley, W. M., and Curtis, E. M. (1958). Bone marrow and fat embolism in sickle cell anemia and sickle cell-haemoglobin $\bar{O}$ C disease. Johns Hopk. med. J., 103, 8-18.

Stern, H. S., McAfee, J. G., and Subramanian, G. (1966). Preparation, distribution and utilization of technetium-99m-sulphur colloid. $\stackrel{\vec{D}}{\text { J. nucl. Med., 7, 665-675. }}$

Wertha.n, F., Mitchell, N., and Angrist, A. (1942). The brain in sickle cell anemia. Arch. Neurol., 47, 752-767. 